\title{
Extent of Application the Governance Principles in the Islamic Banks Operating in Jordan
}

\author{
Dr. Yahya Al-Khasawneh* \\ Faculty of Economics and Administrative Sciences, Zarqa University, Jordan
}

\begin{abstract}
The study aimed to clarify the concept of governance and its objectives and the most important principles underpinning, and to identify on extent of commitment of the Islamic banks operating in Jordan to apply the corporate governance principles for the Islamic banks and the modified instructions outbound by the Central Bank for year 2016. To achieve this purpose has been designing a questionnaire consisted of (30) items were distributed among the study independent and dependent variables, and was testing the sincerity tool and its reliability, and applied on the study sample of (145) employees in the Islamic banks to see how much commitment of these banks to apply the principles of corporate governance of Islamic banks according to the modified instructions. The study results indicated that among respondents have a clear vision of the applicable corporate governance principles at the Islamic banks operating in Jordan, and came these policies ordered as its importance (Maintaining on the shareholders' rights and their transactions fair treatment, Determination the powers and responsibilities of the board of the directors and executive departments and the legitimate of oversight bodies, Providing the transparency and disclosure requirements for the published financial statements, Achievement of the social responsibility towards the community).
\end{abstract}

Keywords: Governance principles, Islamic banks in Jordan, Shareholders' equity, Disclosure and transparency, Legitimate oversight bodies.

\section{INTRODUCTION}

With the growth and proliferation of the Islamic banking industry is in recent years and the evolution of its financing instruments and it raised a lot of voices to demand the development of corporate governance standards to be applied in the Islamic financial and banking institutions similar to what exists in the conventional global institutions, but within the controls and the philosophy of the Islamic law (Al-Taleb, 2013).

The importance of application of the governance in the Islamic banks are increasing because of witnessing the proliferation and expansion is not at the level of Islamic countries alone, but in the world as a whole so it had to the Islamic banks keep abreast of international developments, foremost of which the application of corporate governance principles and in conformity with this particularity banks based on the Islamic law.

\section{MeThodology}

\subsection{The Study Problem \& its Questions}

The governance is of the modern concepts that received on large concerns in recent years via its use in achieving the quality and excellence in performance, they are means to find and organizing the applications and the good practice for those in charge of the company's management so as to maintain the rights of shareholders and the bondholders and the employees of the company and stakeholders and others, through investigated the implementation of formats of the contractual relations including, and using the good financial and accounting instruments, according to the standards of disclosure and transparency of due (Al-Khateeb \& Essam, 2015, Web site).

In light of the foregoing, the study problem can be summarized in the following questions:

a. Does the Islamic banks operating in Jordan is commit by maintaining on the shareholders' rights and their transactions fair treatment? 
b. Does the Islamic banks operating in Jordan to determine the regulations and rules of powers and responsibilities of the board of the directors and executive departments and the legitimate of oversight bodies?

c. Does the Islamic banks operating in Jordan is commit to providing the disclosure and transparency requirements for the published financial statements?

d. Does the Islamic banks operating in Jordan is commit in achievement of the social responsibility towards the community?

\subsection{The Study Importance}

The importance of this study that it deals with a significant issue affecting the essence of the banking organizations, as the banks have become working in the environment of the most important their features the development, innovation and excellence, as the importance of this study being are looking at important sector which is the Islamic banks sector operating in Jordan, as they play a large and important role in the national economy.

\subsection{The Study Objectives}

The study aims to clarify the concept of the governance and its objectives and the most important principles underpinning, also to identify the commitment extent of the Islamic banks operating in Jordan to apply the principles of the corporate governance. In addition, the study aims to identify the following:

a. Extent of maintain of the Islamic banks operating in Jordan on the shareholders' rights and their transactions fair treatment.

b. Extent of existence the regulations and rules in the Islamic banks operating in Jordan to determine the powers and responsibilities of the board of the directors and executive departments and the legitimate of oversight bodies.

c. Extent of commit of the Islamic banks operating in Jordan to providing the disclosure and transparency requirements for financial statements published.

d. Extent of commit of the Islamic banks operating in Jordan in achievement of the social responsibility towards the community.

\subsection{The Study Hypotheses}

To achieve the study objectives, the researcher formulating the following hypothesis, as a null hypothesis $\left(\mathrm{H}_{0}\right)$ and are as follows:

$\mathbf{H}_{0}$ : There is no statistically significant differences at the significance level $(\alpha \leq 0.05)$, between the employees responses about application of the corporate governance principles for the Islamic banks and modified instructions outbound by the Central Bank for the year 2016, attributable to some personal and functional characteristics of (gender, age, qualification, and experience years).

And emanate from the study hypothesis a number of sub-hypotheses are:

$\mathbf{H}_{01}$ : There is no statistically significant differences at the significance level $(\alpha \leq 0.05)$, between the employees responses about application of the corporate governance principles for the Islamic banks and modified instructions outbound by the Central Bank for the year 2016, attributable to the (gender).

$\mathbf{H}_{02}$ : There is no statistically significant differences at the significance level ( $\alpha \leq 0.05$ between the employees responses about application of the corporate governance principles for the Islamic banks and modified instructions outbound by the Central Bank for the year 2016, attributable to the (age).

$\mathbf{H}_{03}$ : There is no statistically significant differences at the significance level $(\alpha \leq 0.05)$, between the employees responses about application of the corporate governance principles for the Islamic banks and modified instructions outbound by the Central Bank for the year 2016, attributable to the (qualification).

$\mathbf{H}_{04}$ : There is no statistically significant differences at the significance level $(\alpha \leq 0.05)$, between the employees responses about application of the corporate governance principles for the Islamic banks and modified instructions outbound by the Central Bank for the year 2016, attributable to the (experience years). 


\section{THEORETICAL FrAMEWORK \& LITERATURE REVIEW}

\subsection{Theoretical Framework}

\subsubsection{Governance Concept}

The governance as language of the source (judgment), and means the prevention and elimination (the fundamental, As-sahah, judgment substance), where it is called the judgment and is intended to eliminate That Allah says (ومن يؤت الحكمة فقد أوتي خيراً كثير (Al-Bakare, 296).

As for the governance idiomatically there are a set of definitions can be described as follows:

a. The concept of the governance as mentioned in the definition of Organization for Economic Cooperation and Development (OECD) as: set of the relationships between each of the institution management of and its administrative board and its shareholders and other interested Parties (Joudeh, 2008: 16).

b. The governance is: a comprehensive system that includes measures of the good performance management and indicators about the existence of oversight methods to prevent any party from the parties related to the facility internally and externally, to influence in a negative on the facility activities, thus ensuring the optimal use of available resources to serve the interests of all parties in a fair way achieved the positive role for the facility in favor of its owners and the community as a whole (Al-hizan, 2005: 9).

c. The governance is: the rational practice for the management authorities through building on the laws, standards and the disciplined rules that determine the relationship between the company's management on the one hand and their shareholders and stakeholders or parties related to the company on the other hand (Sami, 2005: 86).

And the governance in Islamic banks defines as: a set of the laws and regulations that provide sound information for the Board of Directors in the Islamic banks, such as the disclosure and transparency and clarity, so as to achieve the objectives that are in the best interests of the bank customers and their shareholders, and depend on the legal and regulatory systems, in addition to other factors, such as banking business ethics of trust, sincerity, and secretariat (Farhan \& Abdul Qader, 2014: 18).

And defined by one researcher as: regulations, applications, and intact practices applied by the Islamic banks to achieve the fair treatment for the shareholders and employees of the Islamic banks to prove their rights and to ensure the efficiency of application of the operational procedures in isolation from the personal interests, and thus are channeling funds to their optimum utilization, to prevent any cases of the corruption that may it is associated with this, and adopt all of the disclosure and transparency standards and the accounting standards (Suleiman, 2006: 282).

\subsubsection{Governance Legitimacy}

Could be highlighted the evidence by which they can devise legitimacy of the governance in the modern form as follows (As-Salahin, 2010: 13-15):

a. Group of the texts which indicates to the necessity of mastering the work, such as saying, peace be upon and blessings of (that God loves when one of you to do it well). Undoubtedly that mastering the work must pass through the governance, because the governance is one of the most important guaranteeing of safeguards to master the work.

b. Group of the religious texts which stated induces the Promotion of Virtue and Prevention of Vice, and these texts are:

$$
\begin{aligned}
& \text {-1 كنتم خير أمة أخرجت للناس تأمرون بالمعروف وتنهون عن المنكر وتؤمنون باله ولو آمن أهل الكتاب لكان خيراً لهم، منهم }
\end{aligned}
$$

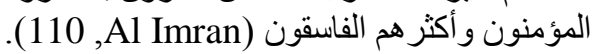

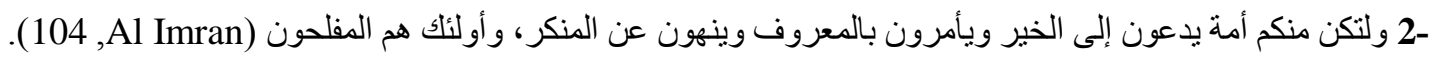

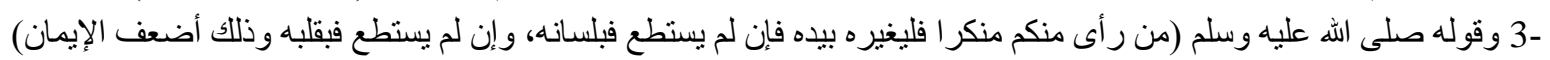

. (78 ciretoeN ,htiaF fo kooB ,milsuM hihaS

These texts came to confirm the Promotion of Virtue and Prevention of Vice, enters mildly forbidding what all denier, whether it is evil acts of worship or transactions or other, no doubt that the lack of commitment to legitimacy controls for the banking transactions is one of the evils that tends Prevention her, and to be bound by these controls it is well Virtue that it must be done. 
c. Group of the texts that came to emphasize the secretariat in order to preservation and warning against of that its infidelity:

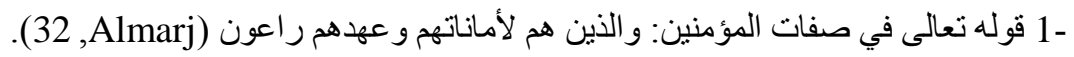

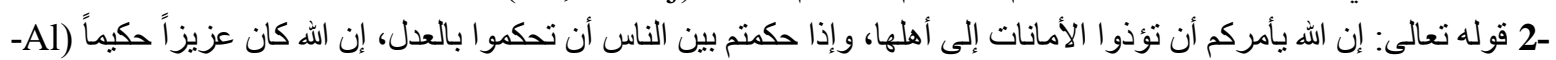

$$
\begin{aligned}
& \text {. (58, aaseN } \\
& \text {-3 وقوله تعالى: يا أيها الذين آمنو الا تخونوا الله و الرسول وتخونو ا أماناتكم و أنتم تعلمون }
\end{aligned}
$$

. 27 , lafnA-1A

\subsubsection{Corporate Governance Importance}

We have grown in recent times the importance of the corporate governance in order to achieve the development and strengthen oversight, and to achieve the economic well of the peoples, and can be summarized the governance importance and its objectives, including the following (Farhan \& Abdul Qader, 2014: 20):

1. Achieve the economic development and avoid falling into the cause of the global financial crisis, in addition to gaining the confidence of clients in the financial markets, and thus achieve the desired economic progress.

2. Fighting the financial and administrative corruption in companies and do not let its existence or his return again.

3. Achievement ensure of the integrity, impartiality and honesty for all employees in the company, starting with the Board of Directors and executives through to the lowest level of employees.

4. Avoid exists any errors or intentional deviation, or unintentional and preventing its continuation, and work to reduce it to a minimum, using the most advanced regulatory regimes.

5. Make the most of the accounting and internal oversight systems and to achieve the effectiveness.

6. Expenditure and linked to the spending with production.

7. Achieve a sufficient amount of the disclosure and transparency in the financial disclosures and data.

8. Protect the investments from exposure to the loss due to misuse of the power in the interest of the investors.

\subsubsection{Governance Delimiters}

The good application for the governance in the facilities on the two sets of determinants depended, an internal delimiters and external delimiters, and can be illustrated as follows (Adel \& et al., 2010: 6):

\section{a. The Internal Delimiters}

The rules and the basis that determine the method of decision-making and the distribution of powers between the General Assembly and the Board of Directors and the managers so as to reduction the contradiction between the interests of these parties.

\section{b. The External Delimiters}

The external delimiters represented by the organizational elements include the overall investment climate in the state, which includes the laws of the market and the efficiency of the financial sector and to provide the necessary funding for projects and competitive degree of the goods market and elements of the production and efficiency of the devices and the oversight bodies and installations working in the finance markets and investment companies, and to special elements include stakeholders and private establishments and professionals from accountants, the auditors, and legal experts and other external parties.

There are a set of factors that must be met to practice good corporate governance in banks represented by (Joudeh, 2008: 52):

1. The central bank issuance of special corporate governance rules of surveillance that are accepted and recognized by all related parties.

2. Must have to the boards of directors and the banks administrations sufficient conviction of the importance of these rules and controls, including helping to implement them. 
3. Availability a clear strategy against which to measure the success of the bank and the contribution of the administration and the individuals in this success.

4. To make sure of the efficiency of the board members and the diversity of their experience and full awareness of the corporate governance concept.

5. Necessity availability adequate levels of review and inspection within each bank.

6. Necessity availability the disclosure and transparency in all the bank's business and the administration.

\subsubsection{Governance and Standard of Islamic Financial Services Board}

The Islamic Financial Services Board in Malaysia adopt the Governance principles issued by each of Organization for Economic Co-operation and Development Economic (OECD) and the document of Basel Committee about "strengthening governance in banking organizations", and founded upon them set of guiding principles that should abide by the Islamic financial institution management towards stakeholders.

It has been issued a standard for corporate governance of the Islamic financial institutions in December 2006, under the so-called (guiding principles for the controls of institutions offering Islamic financial services management).

This standard has committed the Islamic financial institutions either to confirm its commitment to the texts of these guiding principles or be given clearly explained of the stakeholders on the causes not adhering to these principles.

The following are the seven guiding principles issued by the Islamic Financial Services Board (IFSB, 2006: 6):

- The First Principle: the Islamic financial services institutions must lay a policy framework for controls comprehensive management determine the roles and strategy functions for each element of the management controls and the mechanisms adopted to counterbalance the Islamic financial services institutions responsibilities towards various stakeholders.

And are intended by elements of management controls each of (Directors Board and its committees, Executive management, Supervisory Board of legality, Reviewers of the internal and external accounts).

And must the Islamic financial services institutions to adopt the recommendations of the relationship that contained an internationally recognized institutions management controls standards such as Organization for Economic Cooperation and Development (OECD) principles and Basel committee paper on Banking Supervision, also must adhere to the circulars / directives take effect issued by the supervisory authorities, and must adhere to the provisions of the Islamic law and its principles.

- The Second Principle: Islamic financial services institutions must ensure that that the preparation of financial and non-financial information reports fulfills the requirements stipulated by the accounting standards of internationally recognized - and be in conformity with the provisions of Islamic law and principles which apply to the Islamic financial services sector and approved by the supervisory authorities in the concerned State.

Also must be on the board of the institution of the Islamic financial formation review committee include at least three members selected by the Board of Directors of the non-executive members who possess the appropriate and adequate experiences in the analysis of financial statements and financial documents.

- The Third Principle: Islamic financial services institutions must be recognize the rights of holders of the investment accounts in follow up performance of their investments and risks related to, and put sufficient means to ensure the preservation these rights and their practice.

Must therefore on the Islamic financial services institutions that bear responsibility of trust funds towards the investment account holders as a speculator in their funds, with the disclosure and transparency about information at the appropriate time.

- The Fourth Principle: Islamic financial services institutions must be adopt proper investment strategy fit in with the risks and the expected returns for the investment account holders (taking into 
account the distinction between the holders of the restricted investment accounts and absolute) in addition to adoption of the transparency in support of any returns.

- The Fifth Principle: must be on the Islamic financial services institutions to formulate appropriate mechanism for obtaining on the law provisions from specialists, and a commitment to the application of Fatwa and for controlling adherence to Sharia in all aspects of its products and its operations and their activities.

And it remains diversity of the legitimate opinions of the permanent characteristics of the Islamic financial services sector, and we must get the internal reviewers and legitimate observers on the necessary and appropriate training to improve their skills in terms of reviewing the extent of adherence to Sharia.

Also must continue to issuance and encourage the initiatives coordination between the legitimate Fatwa as this sector especially and the nation in general benefit from a common understanding and cooperation between Sharia scholars.

- The Sixth Principle: must the Islamic financial services institution adhere to the provisions of Islamic law and principles enshrined in the law scientists decisions for the institution. The institution must allow public inspection on these provisions and principles.

And this requires that the Islamic financial services institution based the transparency in adoption of application of the provisions of Islamic law and their principles issued by the Sharia scientists of the institution, and organization must adherence Central Sharia Board decisions or disclose the reason for non-compliance.

- The Seventh Principle: Islamic financial services institutions must provide the essential and basic information about the investment accounts that managed for the investment account holders and the public sufficiently and timely.

This requires provision of information for investment account holders on ways the expense of profits and asset allocation and investment strategy and mechanisms support the returns.

It also requires provision of information to investment account holders on the foundations of distribution the profits before you open the investment account and the announcement of share each of the institution and investment account holders in the profits according to the requirements of the speculative contract.

\subsubsection{Advantages of Governance in the Islamic Banks}

Characterized Governance in the Islamic banks by the following advantages:

\section{Maintain on Interests of the Holders Absolute and Restricted Investment Accounts:}

The researcher dealt with the principles of corporate governance issued by the Organization for Economic Co-operation and Development, and the principles of governance in banks issued by the Basel Committee for the Global banking supervision principle of preserving the rights of depositors considering that the basis of the deal between the depositors and owners of the usurious banks based on basis of the fixed rate and pre-defined and not to participate with shareholders achieved in their facility of the profit or loss, but in Islamic banking and dealing between the depositor and the bank it is based on the participation in the profit and loss, which means carrying depositors in Islamic banks high risk compared with other depositors at other financial institutions, which in turn requires an effective management and full control clarify the rights and obligations each side (Shawqi, 2009:1415), the same applies to holders of the restricted investment accounts and necessity of providing them with adequate information as bases distribution of profits before opening the investment accounts, and the participation rate in the profits and losses.

\section{Observance the Islamic Accounting Standards:}

Must be on the Islamic banks be accurate when implementing the events and accounting operations for all operations and activities of the bank taking into account the Islamic accounting standards, this is achieved when there are good accounting systems, accountants with experience and high qualifications in the Islamic banks. 
3. Existence an Effective and Efficient of Legitimacy Oversight Body:

The distinguishes of the Islamic banks when speaking about governance is the necessity of a control legitimacy enjoying complete independence able to issuing Fatwa and Shari's rulings as required the diligence controls and conditions of Fatwa without that there will be influences on their members. And the selection and appointment of the legitimate oversight bodies as follows (Al-Sartawi, 2015: 8):

a. Requires in the Shari' a Supervisory Board member should have a susceptibility jurisprudential able to understand the talk of the diligent proficient of the idiosyncratic graduation or elicitation on new issues.

b. Is assigned the Supervisory Board members by the general assembly of shareholders upon nomination by the Directors Board. And should the number of the Commission members must be not less than three members, and the decision of the Commission either unanimously or by majority.

4. Validity of the Banking Operations of Legitimacy Aspects:

Is represented by commitment of the Islamic banks sincerity and clarity and full frankness between the bank and its clients and staff, in addition to the choice of the best ways to hire the funds and work on the their development under rational management and to achieve the individuals needs and the needs of the Muslim community (Mustafa, 2006: 335).

\section{Achievement of the Social Responsibility towards the Community:}

The distinguishes of the social responsibility for the Islamic banks towards society is collect the Zakat from depositors or shareholders and distributed to eligible applicants, in addition to do and contribute in some charitable works through their dealings with savers and investors, and the extent of achieving the economic and social development within the communities which you are located, and the fulfillment of the social obligations towards the environment in which it operates to sacrifice by fraction of their profits in order to service of the environment such as pollution control, personnel training, and provide gifts and donations to associations and public institutions (Al-Hanini \& et al, 2013: 222).

There are set of principles which conform in it the Islamic banks with the usurious banks and companies in the application of the governance principles, among them the following:

1. Maintaining on Shareholders' Equity and Stakeholders and their Dealings Fair Treatment:

Is representing this by setting a specific mechanism to ensure communication with the stakeholders shareholders through disclosure and provide an information indication about the bank's activities to stakeholders through meetings of the General Authority, the annual report, the website of the Bank, Department of shareholders relations, and ensure fair treatment for all shareholders and protect their rights, especially the minority shareholders and protect them from any action which might lead to harm their interests (Farhan, 2014: 20).

\section{Achieve of Disclosure and Transparency:}

Is representing this by publication of the financial and non-financial information of interest the stakeholders, and that the annual report of the bank includes a text stating that the council responsible for the accuracy and adequacy of the bank's financial statements and the information contained in that report.

\section{Responsibilities of the Directors Board:}

Is represented by doing the Board of Directors to issue organizational instructions which formed the administrative structure of the Bank and its objectives, and dividing the business so that would facilitate the determination the roles of units, managers and the bank's branches, and assembling the units and its organizing hierarchically and clarify vertical and horizontal communication lines and the devolution of powers and authorities, and performance assessment periodically in light of the overall objectives and specific roles per unit (Al-Ajlouni, 2010: 126).

\section{Integrity of the Rules of Procedure of the Bank:}

This principle means that necessity a timely and proper distribution for tasks and responsibilities by having a management structure that determines the powers and responsibilities for the senior 
management Board, executives, and employees, as well as keep abreast of the internal systems of developments and provide a clear strategy for the bank (Farhan, 2014: 21).

\subsection{Literature Review}

- Study of (Farhan \& Abdul Qadir, 2014), entitled: The governance in the Yemeni of Islamic banks - An Applied Study.

The study aimed to identify the governance principles in the Islamic banks and measuring the extent of application of those principles in the Yemeni of Islamic banks. The findings of this study, are the Yemeni of Islamic banks apply the principles of the governance recognized with a commitment to take into account the nature of the Islamic distinctive, and these banks are committed to the principle of maintaining the shareholders' rights and the rights of stakeholders and providing the disclosure and transparency requirements for the financial statements published.

The study recommended necessity of raise the level of interest in application of the governance principles with a commitment to take into account the nature of the Islamic distinctive, in addition to the interest in maintaining of the employee rights, the most important provision of the justice in salaries, incentives and wage system, and the increased interest in reviewing the regulations and statutes governing the work of the banks so as to ensure clear identification and sound for the powers and responsibilities for each of the board of Directors and the executive administrations and the board of Sharia Supervisory.

- Study of (Bu Raqaba, 2014), entitled: Impact of application of the corporate governance rules in the Islamic banks performance- An Applied Study.

The study aimed to determine the relationship between the corporate governance principles and the financial performance of the Islamic banks and measure the impact of the corporate governance principles in the financial performance through practical study on a sample of the Islamic banks during the period (2005 - 2012).

The study reached to a positive correlation between the financial performance of the Islamic banks (return on assets) and the governance based on the Board of Directors structure and number of directors and the number of committees in the boardroom and the number of Shari'a Supervisory Board members in addition to focus the stock with proportion of the owned shares by the major shareholders.

- Study of (Meshaal, 2010), entitled: Governance of the Islamic banks.

The study aimed to statement the origins and evolution of the corporate governance of the Islamic banks, and the statement of the corporate governance requirements in the control system and the internal audit forensic and development of the corporate governance clues on the supervisory authority level as well take a look at the future of the corporate governance in the Islamic banks.

- Study of (Siyam, 2009), entitled: Role of Banking governance in enhancing the efficiency of the Jordanian commercial banks.

The study aimed to identify the nature of the governance and their determinants and identify the most important factors affecting in enhance the efficiency of the Jordanian commercial banks, in addition to determining the role of the governance in the Jordanian banking sector. And to clarify the role of the banking corporate governance in enhance the competitiveness of the Jordanian commercial banks. The study concluded there the clear quantitative evolution on the number of banks and their branches operating in Jordan, which refers to the development of the banking awareness among different segments of society that on one hand, and the feasibility of the investment in this sector on the other hand, and reinforced this the procedures of the economic openness and application of foundations and principles of the corporate governance, as tended the foreign banks to enter the Jordanian market recently and it has been open for three new branches of foreign banks. And through tighter control and application of the corporate governance principles witnessed clause of the total deposits continuous growth by for promote trust, and the credit facilities experienced the high levels in size, and thus demonstrate their importance in showing an image-based economic of activity and features of stage when applied the governance.

The study recommended that the banking sector seeks toward maximizing the value of its assets and its liquidity and margins of profitability, through the efficient management and tighter control since 
they constitute an attraction for both savers and investors alike. The transition from the concept of traditional banks into universal banks to achieve optimum utilization of available resources in light of the challenges posed by globalization of the survival of the finest. And the governance should take into account the banking merger as one of the supportive measures to achieve a competitive of the banking sector.

- Study of (Jubair, 2008), entitled: Extent of commitment of the Jordanian professional associations to apply the corporate governance principles.

The study aimed to measure the extent of commitment of the Jordanian professional associations to apply the corporate governance principles, and the most important findings of the study that the Jordanian professional associations is committed to applying the corporate governance principles with level of commitment ranged between (medium and high), and the study recommendations to urge the Jordanian professional associations commitment to apply the governance institutional especially the Jordanian Engineers Association.

- Study of (Mutter \& Noor, 2007), entitled: Extent of commitment of the Jordanian public shareholding companies operating in the banking and industry to the corporate governance principles.

This study aimed to evaluate the extent of commitment of the Jordanian public shareholding companies to the corporate governance principles, and to achieve this objective the researchers conducted a field study on the number of the Jordanian public shareholding companies in the banking and industrial sectors.

The researchers reached to a set of the results which the most important was that the commitment level to the public shareholding companies in sectors ranging from (strong and very weak), and there are aspects of the imbalance in application of the system take hold in the lack of commitment by the directors of professional boards of the conduct rules. Also the study it recommended a set of recommendations perhaps the most important of which initiates the control and supervision entities on those companies through issuing guide explains the basic principles of the corporate governance system.

\section{Method And Procedures}

\subsection{The Study Approach}

The study used the descriptive and analytical approach to accomplish this study, and was used the descriptive method to describe the extent of commitment of the Islamic banks operating in Jordan to apply the corporate governance principles, also been used as the analytical method to measure the differences between the employees responses about the application of the governance principles in Islamic banks operating in Jordan, attributable to some personal and functional characteristics of (gender, age, qualification, and experience years).

\subsection{The Study Population and its Sample}

The study population consists of all the employees in the Islamic Banks operating in Jordan. The sample was chosen from the study population, by using the simple random sample method, therefore the final study sample was amounted (160) employees. After that the researcher distributed (160) questionnaire on the study sample, were returned (151) questionnaire, where the percentage of questionnaires returned is (94\%), and after review and audit questionnaires returned, were excluded (6) questionnaires because lack of the information contained in each, and thus the number of valid questionnaires for the statistical analysis (145) questionnaire.

\subsection{The Study Tool}

The researcher reference to the relevant studies and researches, view to designing a questionnaire of study for the purposes of collecting information and data, where the questionnaire consisted of two parts:

Part (1): included general information (demographic variables): represented by (gender, age, educational qualification, and experience years).

Part (2): This section includes the items of the study variables.

The final tool consisted of (30) items distributed on the study variables, after completion of design the study tool was measured the tool sincerity and its reliability, as follows: 


\section{a. Tool Sincerity}

Has been verified the Face Validity of the study tool (questionnaire), and through the presentation on three arbitrators with expertise and knowledge from teaching faculty members at Jordanian universities, in the terms of reference of administrative sciences, and was the aim of the arbitration verify the extent of items belonging to the study variables, an appropriate degree of drafting items Linguistically, where been modification reworded drafting some of items.

\section{b. Tool Reliability}

Having been assured of the study tool validity and the readiness of its application, on the study sample of (145) employees, and for the purpose of verifying of the internal consistency of the questionnaire items of the study variables, the researcher used for this purpose (Cronbach's alpha) coefficient to measure the (internal consistency of the questionnaire items), which equals to the total tool (0.61.8), and this value is very good for the administrative and humanitarian researches. As shown in the following Table (1):

Table1. Results of reliability (Internal Consistency of the items)

\begin{tabular}{|c|c|c|c|c|}
\hline No. & Governance principles & N & Cronbach's Alpha & Stability Ratio \\
\hline 1 & $\begin{array}{c}\text { Maintaining on the shareholders' rights and their } \\
\text { transactions fair treatment }\end{array}$ & 8 & 0.629 & $\% 62.9$ \\
\hline 2 & $\begin{array}{c}\text { Determination the powers, responsibilities of the } \\
\text { board of the directors, and executive departments } \\
\text { and the legitimate of oversight bodies }\end{array}$ & 11 & 0.776 & $\% 77.6$ \\
\hline 3 & $\begin{array}{c}\text { Providing the disclosure and transparency } \\
\text { requirements for the published financial statements }\end{array}$ & 5 & 0.713 & $\% 71.3$ \\
\hline 4 & $\begin{array}{c}\text { Achievement of the social responsibility towards } \\
\text { the community }\end{array}$ & 6 & 0.654 & $\% 65.4$ \\
\hline- & Overall Tool & $\mathbf{3 0}$ & $\mathbf{0 . 6 1 8}$ & $\mathbf{\% 6 1 . 8}$ \\
\hline
\end{tabular}

\section{RESUlTS AND DiscuSSION}

This section devoted to present the results of the statistical analysis of the data subjects' responses of the study sample, which was reached through the use of the Statistical Package for Social Sciences (SPSS), where the researcher use some of the statistical methods: (Means \& Standard Deviations, Cronbch's Alpha Coefficient, and Kruskal-Wallis Test).

In order to answer the study questions and test the hypotheses as follows:

\subsection{Results Related to the Study Question}

What Application Level of the Corporate Governance Principles for the Islamic Banks and Modified Instructions from the Perspective of their Employees?

For the purpose of answering on the study question, were account the means, standard deviations in order to stand on the estimates of employees in the Islamic Banks operating in Jordan about of their evaluation level of application level of the corporate governance principles for the Islamic banks and modified instructions. As shown in Table (2):

Table2. Results of Means and Standard Deviations for the corporate governance principles for the Islamic banks and modified instructions

\begin{tabular}{|c|c|c|c|c|c|}
\hline No. & Governance principles & Mean & Std. Dev. & Rank & Application level \\
\hline 1 & $\begin{array}{c}\text { Maintaining on the shareholders' rights } \\
\text { and their transactions fair treatment }\end{array}$ & 3.98 & 0.41 & 2 & High \\
\hline 2 & $\begin{array}{c}\text { Determination the powers, responsibilities } \\
\text { of the board of the directors, and } \\
\text { executive departments and the legitimate } \\
\text { of oversight bodies }\end{array}$ & 3.61 & 0.49 & 4 & Median \\
\hline 3 & $\begin{array}{c}\text { Providing the disclosure and transparency } \\
\text { requirements for the published financial } \\
\text { statements }\end{array}$ & 3.88 & 0.34 & 3 & High \\
\hline 4 & $\begin{array}{c}\text { Achievement of the social responsibility } \\
\text { towards the community }\end{array}$ & 4.01 & 0.27 & 1 & High \\
\hline- & General Mean & $\mathbf{3 . 7 8}$ & $\mathbf{0 . 5 1}$ & - & High \\
\hline
\end{tabular}


Evident from the results in Table (2), that the (Achievement of the social responsibility towards the community) principle get on the (first) rank in terms of its importance for the study sample, with mean was (4.01) and standard deviation (0.27), and the (Maintaining on the shareholders' rights and their transactions fair treatment) principle get on the (second) rank, with mean was (3.98) and standard deviation (0.41), while the (Providing the transparency and disclosure requirements for the published financial statements) principle get on the (third) rank, with mean was (3.88) and standard deviation (0.34), and finally the (Determination the powers, responsibilities of the board of the directors, and executive departments and the legitimate of oversight bodies) principle came in the (forth) rank and the last on the ladder of priorities for the employees estimates in the Islamic Banks operating in Jordan, with mean was (3.61) and standard deviation (0.49).

\subsection{Results Related to Test the Hypotheses}

$\mathbf{H}_{0}$ : There is no statistically significant differences at the significance level $(\alpha \leq 0.05)$, between the employees responses about application of the corporate governance principles for the Islamic banks and modified instructions outbound by the Central Bank for the year 2016, attributable to some personal and functional characteristics of (gender, age, qualification, and experience years).

To test validity of the study hypothesis or not validity, was used the Kruskal- Wallis Test. And to achieve this, it should make sure validity of the sub-hypotheses emanating from it or not, as follows:

\subsubsection{Results Related to Test the $1^{\text {st }}$ Sub-hypothesis}

$\mathbf{H}_{01}$ : There is no statistically significant differences at the significance level $(\alpha \leq 0.05)$, between the employees responses about application of the corporate governance principles for the Islamic banks and modified instructions outbound by the Central Bank for the year 2016, attributable to the (gender).

In order to test validity of the $1^{\text {st }}$ sub-hypothesis or not validity, was used the Kruskal- Wallis Test. As shown in the following Table (3):

Table3. Results of Kruskal- Wallis Test, to measure the differences between the employees responses about application of the corporate governance principles for the Islamic banks and modified instructions, attributable to the (gender)

\begin{tabular}{|c|c|c|c|c|c|c|}
\hline Governance principles & Gender & $\mathbf{N}$ & $\begin{array}{l}\text { Ranks } \\
\text { Mean }\end{array}$ & $\begin{array}{c}\chi^{2} \\
\text { value }\end{array}$ & df. & Sig. \\
\hline \multirow{2}{*}{$\begin{array}{l}\text { Maintaining on the shareholders' rights and their } \\
\text { transactions fair treatment }\end{array}$} & Male & 96 & 63.48 & \multirow[b]{2}{*}{14.820} & \multirow[b]{2}{*}{1} & \multirow[b]{2}{*}{0.000} \\
\hline & Female & 49 & 91.64 & & & \\
\hline \multirow{2}{*}{$\begin{array}{l}\text { Determination the powers, responsibilities of the } \\
\text { board of the directors, and executive departments and } \\
\text { the legitimate of oversight bodies }\end{array}$} & Male & 96 & 81.10 & \multirow[b]{2}{*}{10.740} & \multirow[b]{2}{*}{1} & \multirow[b]{2}{*}{0.001} \\
\hline & Female & 49 & 57.13 & & & \\
\hline \multirow{2}{*}{$\begin{array}{l}\text { Providing the disclosure and transparency } \\
\text { requirements for the published financial statements }\end{array}$} & Male & 96 & 75.57 & \multirow[b]{2}{*}{1.135} & \multirow[b]{2}{*}{1} & \multirow[b]{2}{*}{0.287} \\
\hline & Female & 49 & 67.96 & & & \\
\hline \multirow{2}{*}{$\begin{array}{l}\text { Achievement of the social responsibility towards the } \\
\text { community }\end{array}$} & Male & 96 & 72.48 & \multirow[b]{2}{*}{0.048} & \multirow[b]{2}{*}{1} & \multirow[b]{2}{*}{0.827} \\
\hline & Female & 49 & 74.02 & & & \\
\hline
\end{tabular}

[Tabulated $\left(\chi^{2}\right)$ with $d f .=1$ at the significance level $\left.(\alpha=0.05)\right]=3.841$

It is evident from the results listed in the Table (3), that:

a. There were no statistically significant differences at the significance level $(\alpha=0.05)$, between the employees responses about two principles of the governance principles which are (Providing the disclosure and transparency requirements for the published financial statements, and achievement of the social responsibility towards the community) in the Islamic banks operating in Jordan, attributable to the (gender), which is supported by the calculated values of $\left(\chi^{2}\right.$-test) which are $(1.135,0.048)$ respectively for the mentioned principles, and all the values are less than the tabulated $\left(\chi^{2}\right)$ amounted (3.841), also the (Sig.) values for these principles were greater than the significance level $(\alpha=0.05)$. This means that the employees responses about the mentioned principles to be equivalents to have regardless of their genders. This means that will be not rejecting the null sub-hypothesis $\left(\mathrm{H}_{01}\right)$ partially.

b. There exist statistically significant differences at the significance level $(\alpha=0.05)$, between the employees responses about two principles of the governance principles which are (Maintaining on the shareholders' rights and their transactions fair treatment, and determination the powers, 


\section{Dr. Yahya Al-Khasawneh}

responsibilities of the board of the directors, and executive departments and the legitimate of oversight bodies) in the Islamic banks operating in Jordan, attributable to the (gender), which is supported by the calculated values of $\left(\chi^{2}\right.$-test) which are $(14.820,10.740)$ respectively for the mentioned principles, and all the values are greater than the tabulated $\left(\chi^{2}\right)$ amounted (3.841), also the (Sig.) values for these principles are less than the significance level $(\alpha=0.05)$. This means that will be reject the null sub-hypothesis $\left(\mathrm{H}_{01}\right)$ partially. And these differences was in favor of the (females) according to the (first) principle, and the (males) according to the (second) principle in terms of the ranks mean $(91.64,81.10)$ respectively, and the ranks mean are greater than the categories ranks mean of the other (gender) for the mentioned principles.

\subsubsection{Results Related to test the $2^{\text {nd }}$ Sub-hypothesis}

$\mathbf{H}_{02}$ : There is no statistically significant differences at the significance level $(\alpha \leq 0.05)$, between the employees responses about application of the corporate governance principles for the Islamic banks and modified instructions outbound by the Central Bank for the year 2016, attributable to the (age).

In order to test validity of the $2^{\text {nd }}$ sub-hypothesis or not validity, was used the Kruskal- Wallis Test. As shown in the following Table (4):

Table4. Results of Kruskal- Wallis Test, to measure the differences between the employees responses about application of the corporate governance principles for the Islamic banks and modified instructions, attributable to the (age)

\begin{tabular}{|c|c|c|c|c|c|c|}
\hline Governance principles & Age & $\mathbf{N}$ & $\begin{array}{l}\text { Ranks } \\
\text { Mean }\end{array}$ & $\begin{array}{c}\chi^{2} \\
\text { value }\end{array}$ & df. & Sig. \\
\hline \multirow{4}{*}{$\begin{array}{l}\text { Maintaining on the shareholders' rights } \\
\text { and their transactions fair treatment }\end{array}$} & $18-30$ & 13 & 56.69 & \multirow{4}{*}{15.367} & \multirow{4}{*}{3} & \multirow{4}{*}{0.002} \\
\hline & $30-40$ & 44 & 92.43 & & & \\
\hline & $40-50$ & 61 & 68.79 & & & \\
\hline & 50 year $>$ & 27 & 58.70 & & & \\
\hline \multirow{4}{*}{$\begin{array}{l}\text { Determination the powers, } \\
\text { responsibilities of the board of the } \\
\text { directors, and executive departments } \\
\text { and the legitimate of oversight bodies }\end{array}$} & $18-30$ & 13 & 92.54 & \multirow{4}{*}{14.093} & \multirow{4}{*}{3} & \multirow{4}{*}{0.003} \\
\hline & $30-40$ & 44 & 54.17 & & & \\
\hline & $40-50$ & 61 & 80.36 & & & \\
\hline & 50 year $>$ & 27 & 77.65 & & & \\
\hline \multirow{4}{*}{$\begin{array}{l}\text { Providing the disclosure and } \\
\text { transparency requirements for the } \\
\text { published financial statements }\end{array}$} & $18-30$ & 13 & 86.46 & \multirow{4}{*}{8.762} & \multirow{4}{*}{3} & \multirow{4}{*}{0.033} \\
\hline & $30-40$ & 44 & 64.99 & & & \\
\hline & $40-50$ & 61 & 68.30 & & & \\
\hline & 50 year $>$ & 27 & 90.20 & & & \\
\hline \multirow{4}{*}{$\begin{array}{l}\text { Achievement of the social } \\
\text { responsibility towards the community }\end{array}$} & $18-30$ & 13 & 63.12 & \multirow{4}{*}{3.647} & \multirow{4}{*}{3} & \multirow{4}{*}{0.302} \\
\hline & $30-40$ & 44 & 66.30 & & & \\
\hline & $40-50$ & 61 & 79.56 & & & \\
\hline & 50 year $>$ & 27 & 73.87 & & & \\
\hline
\end{tabular}

[Tabulated $\left(\chi^{2}\right)$ with $d f .=3$ at the significance level $\left.(\alpha=0.05)\right]=7.815$

It is evident from the results listed in the Table (4), that:

a. There were no statistically significant differences at the significance level $(\alpha=0.05)$, between the employees responses about the principle of the governance principles which is (achievement of the social responsibility towards the community) in the Islamic banks operating in Jordan, attributable to the (age), which is supported by the calculated value of ( $\chi^{2}$-test) which are (3.647) for the mentioned principle, and the value is less than the tabulated $\left(\chi^{2}\right)$ amounted (7.815), also the (Sig.) value for this principle is greater than the significance level $(\alpha=0.05)$. This means that the employees responses about the mentioned principle to be equivalents to have regardless of their ages. This means that will be not rejecting the null sub-hypothesis $\left(\mathrm{H}_{02}\right)$ partially.

b. There exist statistically significant differences at the significance level $(\alpha=0.05)$, between the employees responses about three principles of the governance principles which are (Maintaining on the shareholders' rights and their transactions fair treatment, determination the powers, responsibilities of the board of the directors, and executive departments and the legitimate of oversight bodies, and providing the disclosure and transparency requirements for the published financial statements) in the Islamic banks operating in Jordan, attributable to the (age), which is supported by the calculated values of $\left(\chi^{2}\right.$-test $)$ which are $(15.367,14.093,8.762)$ respectively for the mentioned principles, and all the values are greater than the tabulated $\left(\chi^{2}\right)$ amounted (7.815), also the (Sig.) values for these 
principles are less than the significance level $(\alpha=0.05)$. This means that will be reject the null subhypothesis $\left(\mathrm{H}_{02}\right)$ partially. And these differences was in favor of the age class $(30-40)$ according to the (first) principle, the age class (18 - 30) according to the (second) principle, and the age class (50 year >) according to the (third) principle, in terms of the ranks mean $(92.43,92.54,90.20)$ respectively, and the ranks mean are greater than the categories ranks mean of the other (age) for the mentioned principles.

\subsubsection{Results Related to test the $3^{\text {rd }}$ Sub-hypothesis}

$\mathbf{H}_{\mathbf{0 3}}$ : There is no statistically significant differences at the significance level $(\alpha \leq 0.05)$, between the employees responses about application of the corporate governance principles for the Islamic banks and modified instructions outbound by the Central Bank for the year 2016, attributable to the (qualification).

In order to test validity of the $3^{\text {rd }}$ sub-hypothesis or not validity, was used the Kruskal- Wallis Test. As shown in the following Table (5):

Table5. Results of Kruskal- Wallis Test, to measure the differences between the employees responses about application of the corporate governance principles for the Islamic banks and modified instructions, attributable to the (qualification)

\begin{tabular}{|c|c|c|c|c|c|c|}
\hline Governance principles & Qualification & $\mathbf{N}$ & $\begin{array}{l}\text { Ranks } \\
\text { Mean }\end{array}$ & $\begin{array}{c}\chi^{2} \\
\text { value }\end{array}$ & df. & Sig. \\
\hline \multirow{4}{*}{$\begin{array}{l}\text { Maintaining on the shareholders' rights } \\
\text { and their transactions fair treatment }\end{array}$} & Diploma and less & 39 & 69.86 & \multirow{4}{*}{1.150} & \multirow{4}{*}{3} & \multirow{4}{*}{0.765} \\
\hline & Bachelor & 81 & 72.46 & & & \\
\hline & Master & 23 & 78.37 & & & \\
\hline & Doctorate & 2 & 94.50 & & & \\
\hline \multirow{4}{*}{$\begin{array}{l}\text { Determination the powers, } \\
\text { responsibilities of the board of the } \\
\text { directors, and executive departments } \\
\text { and the legitimate of oversight bodies }\end{array}$} & Diploma and less & 39 & 67.74 & \multirow{4}{*}{3.735} & \multirow{4}{*}{3} & \multirow{4}{*}{0.291} \\
\hline & Bachelor & 81 & 76.15 & & & \\
\hline & Master & 23 & 74.96 & & & \\
\hline & Doctorate & 2 & 25.50 & & & \\
\hline \multirow{4}{*}{$\begin{array}{l}\text { Providing the disclosure and } \\
\text { transparency requirements for the } \\
\text { published financial statements }\end{array}$} & Diploma and less & 39 & 64.46 & \multirow{4}{*}{6.657} & \multirow{4}{*}{3} & \multirow{4}{*}{0.084} \\
\hline & Bachelor & 81 & 73.83 & & & \\
\hline & Master & 23 & 87.93 & & & \\
\hline & Doctorate & 2 & 34.25 & & & \\
\hline \multirow{4}{*}{$\begin{array}{l}\text { Achievement of the social } \\
\text { responsibility towards the community }\end{array}$} & Diploma and less & 39 & 67.92 & \multirow{4}{*}{2.400} & \multirow{4}{*}{3} & \multirow{4}{*}{0.494} \\
\hline & Bachelor & 44 & 77.51 & & & \\
\hline & Master & 16 & 65.70 & & & \\
\hline & Doctorate & 2 & 73.50 & & & \\
\hline
\end{tabular}

It is evident from the results contained in the Table (5), that there were no statistically significant differences at the significance level $(\alpha=0.05)$, between the employees responses about all principles of the governance principles which are (Maintaining on the shareholders' rights and their transactions fair treatment, determination the powers, responsibilities of the board of the directors, and executive departments and the legitimate of oversight bodies, providing the disclosure and transparency requirements for the published financial statements, and achievement of the social responsibility towards the community) in the Islamic banks operating in Jordan, attributable to the (qualification), which is supported by the calculated values of $\left(\chi^{2}\right.$-test $)$ which are $(1.150,3.735,6.657,2.400)$ respectively for the mentioned principles, and all the values are less than the tabulated $\left(\chi^{2}\right)$ amounted (7.815), also the (Sig.) values for these principles were greater than the significance level $(\alpha=0.05)$. This means that the employees responses about the mentioned principles to be equivalents to have regardless of their qualifications. This means that will be not rejecting the null sub-hypothesis $\left(\mathrm{H}_{03}\right)$.

\subsubsection{Results Related to Test the $4^{\text {th }}$ Sub-hypothesis}

$\mathbf{H}_{04}$ : There is no statistically significant differences at the significance level $(\alpha \leq 0.05)$, between the employees responses about application of the corporate governance principles for the Islamic banks and modified instructions outbound by the Central Bank for the year 2016, attributable to the (experience years).

In order to test validity of the $4^{\text {th }}$ sub-hypothesis or not validity, was used the Kruskal- Wallis Test. As shown in the following Table (6): 
Table6. Results of Kruskal- Wallis Test, to measure the differences between the employees responses about application of the corporate governance principles for the Islamic banks and modified instructions, attributable to the (experience years)

\begin{tabular}{|c|c|c|c|c|c|c|}
\hline Governance principles & $\begin{array}{l}\text { Experience } \\
\text { years }\end{array}$ & $\mathbf{N}$ & $\begin{array}{l}\text { Ranks } \\
\text { Mean }\end{array}$ & $\begin{array}{c}\chi^{2} \\
\text { value }\end{array}$ & df. & Sig. \\
\hline \multirow{4}{*}{$\begin{array}{l}\text { Maintaining on the shareholders' rights and } \\
\text { their transactions fair treatment }\end{array}$} & $>5$ years & 22 & 39.93 & \multirow{4}{*}{31.734} & \multirow{4}{*}{3} & \multirow{4}{*}{0.000} \\
\hline & $5-10$ & 28 & 52.86 & & & \\
\hline & $10-15$ & 57 & 90.44 & & & \\
\hline & 15 year $>$ & 38 & 80.83 & & & \\
\hline \multirow{4}{*}{$\begin{array}{c}\text { Determination the powers, responsibilities of } \\
\text { the board of the directors, and executive } \\
\text { departments and the legitimate of oversight } \\
\text { bodies }\end{array}$} & $>5$ years & 22 & 71.25 & \multirow{4}{*}{7.186} & \multirow{4}{*}{3} & \multirow{4}{*}{0.066} \\
\hline & $5-10$ & 28 & 76.70 & & & \\
\hline & $10-15$ & 57 & 63.15 & & & \\
\hline & 15 year $>$ & 38 & 86.07 & & & \\
\hline \multirow{4}{*}{$\begin{array}{l}\text { Providing the transparency and disclosure } \\
\text { requirements for the published financial } \\
\text { statements }\end{array}$} & $>5$ years & 22 & 72.85 & \multirow{4}{*}{1.555} & \multirow{4}{*}{3} & \multirow{4}{*}{0.670} \\
\hline & $5-10$ & 28 & 65.93 & & & \\
\hline & $10-15$ & 57 & 77.43 & & & \\
\hline & 15 year $>$ & 38 & 71.62 & & & \\
\hline \multirow{4}{*}{$\begin{array}{l}\text { Achievement of the social responsibility } \\
\text { towards the community }\end{array}$} & $>5$ years & 22 & 67.73 & \multirow{4}{*}{24.230} & \multirow{4}{*}{3} & \multirow{4}{*}{0.000} \\
\hline & $5-10$ & 28 & 52.30 & & & \\
\hline & $10-15$ & 57 & 68.05 & & & \\
\hline & 15 year $>$ & 38 & 98.72 & & & \\
\hline
\end{tabular}

It is evident from the results listed in the Table (6), that:

a. There were no statistically significant differences at the significance level $(\alpha=0.05)$, between the employees responses about two principles of the governance principles which are (Determination the powers, responsibilities of the board of the directors, and executive departments and the legitimate of oversight bodies, and Providing the transparency and disclosure requirements for the published financial statements) in the Islamic banks operating in Jordan, attributable to the (experience years), which is supported by the calculated value of $\left(\chi^{2}\right.$-test) which are $(7.186,1.555)$ respectively for the mentioned principles, and the values are less than the tabulated $\left(\chi^{2}\right)$ amounted (7.815), also the (Sig.) value for this principles are greater than the significance level $(\alpha=0.05)$. This means that the employees responses about the mentioned principles to be equivalents to have regardless of their experience years. This means that will be not rejecting the null sub-hypothesis $\left(\mathrm{H}_{04}\right)$ partially.

b. There exist statistically significant differences at the significance level $(\alpha=0.05)$, between the employees responses about two principles of the governance principles which are (Maintaining on the shareholders' rights and their transactions fair treatment, and achievement of the social responsibility towards the community) in the Islamic banks operating in Jordan, attributable to the (experience years), which is supported by the calculated values of $\left(\chi^{2}\right.$-test $)$ which are $(31.734,24.230)$ respectively for the mentioned principles, and all the values are greater than the tabulated $\left(\chi^{2}\right)$ amounted (7.815), also the (Sig.) values for these principles are less than the significance level $(\alpha=0.05)$. This means that will be reject the null sub-hypothesis $\left(\mathrm{H}_{04}\right)$ partially. And these differences was in favor of the experience years class $(10-15)$ according to the (first) principle, and the experience years class (15 year $>$ ) according to the (forth) principle, in terms of the ranks mean $(90.44,98.72)$ respectively, and the ranks mean are greater than the categories ranks mean of the other (experience years) for the mentioned principles.

\section{Conclusions}

The study concluded a number of conclusions in light of its results, among them the following:

a. The (achievement of the social responsibility towards the community) principle get on the (first) rank in terms of its importance for the study sample, and the (maintaining on the shareholders' rights and their transactions fair treatment) principle get on the (second) rank, while the (providing the transparency and disclosure requirements for the published financial statements) principle get on the (third) rank, and finally the (determination the powers, responsibilities of the board of the directors, and executive departments and the legitimate of oversight bodies) principle came in the (forth) rank and the last on the ladder of priorities for the employees estimates in the Islamic Banks operating in Jordan. 
b. There were no statistically significant differences at the significance level $(\alpha=0.05)$, between the employees responses about two principles which are (providing the disclosure and transparency requirements for the published financial statements, and achievement of the social responsibility towards the community) in the Islamic banks operating in Jordan, attributable to the (gender).

c. There exist statistically significant differences at the significance level $(\alpha=0.05)$, between the employees responses about two principles of the governance principles which are (Maintaining on the shareholders' rights and their transactions fair treatment, and determination the powers, responsibilities of the board of the directors, and executive departments and the legitimate of oversight bodies) in the Islamic banks operating in Jordan, attributable to the (gender), and these differences was in favor of the (females) according to the (first) principle, and the (males) according to the (second) principle.

d. There were no statistically significant differences at the significance level $(\alpha=0.05)$, between the employees responses about the principle which is (achievement of the social responsibility towards the community) in the Islamic banks operating in Jordan, attributable to the (age).

e. There exist statistically significant differences at the significance level $(\alpha=0.05)$, between the employees responses about three principles of the governance principles which are (Maintaining on the shareholders' rights and their transactions fair treatment, determination the powers, responsibilities of the board of the directors, and executive departments and the legitimate of oversight bodies, and providing the disclosure and transparency requirements for the published financial statements) in the Islamic banks operating in Jordan, attributable to the (age), and these differences was in favor of the age class (30 - 40) according to the (first) principle, the age class (18 - 30) according to the (second) principle, and the age class (50 year >) according to the (third) principle.

f. There were no statistically significant differences at the significance level $(\alpha=0.05)$, between the employees responses about all the governance principles which are (Maintaining on the shareholders' rights and their transactions fair treatment, determination the powers, responsibilities of the board of the directors, and executive departments and the legitimate of oversight bodies, providing the disclosure and transparency requirements for the published financial statements, and achievement of the social responsibility towards the community) in the Islamic banks operating in Jordan, attributable to the (qualification).

g. There were no statistically significant differences at the significance level $(\alpha=0.05)$, between the employees responses about two principles of the governance principles which are (determination the powers, responsibilities of the board of the directors, and executive departments and the legitimate of oversight bodies, and providing the transparency and disclosure requirements for the published financial statements) in the Islamic banks operating in Jordan, attributable to the (experience years).

h. There exist statistically significant differences at the significance level $(\alpha=0.05)$, between the employees responses about two principles of the governance principles which are (maintaining on the shareholders' rights and their transactions fair treatment, and achievement of the social responsibility towards the community) in the Islamic banks operating in Jordan, attributable to the (experience years), and these differences was in favor of the experience years class (10 - 15) according to the (first) principle, and the experience years class (15 year >) according to the (forth) principle.

\section{ACKNOWLEDGEMENT}

This research is funded by the Deanship of Research and Graduate Studies in Zarqa University

\section{REFERENCES}

[1] Al-Ajlouni, Mohamed Mahmoud, (2010), The Islamic banks: its provisions, principles, and banking applications, Dar Al-Massira for publishing and distribution, Amman, Jordan

[2] Al-Sartawi, Mahmoud Ali, (2015), Governance the legitimate oversight bodies in financial institutions, A study submitted to the symposium legitimate bodies between the central and dependency, Amman, Jordan.

[3] Al-Hizan, Osama Fahed, (2005), System of the manage and control installations (governance): A case of accounting and review of the Gulf Cooperation Council for the Arab States in the Gulf, $5^{\text {th }}$ Conference of the corporate and its accounting, administrative, and economic dimensions, Alexandria University, Faculty of Commerce. 
[4] Al-Khateeb, Khaled and Essam, Guriat, (2015), Concepts of the governance and its applications - A case study of Jordan and Egypt, website, dated 16/12/2015.

[5] As-Salahin, Abdul Majeed, (2010), The governance of the Islamic financial institutions, Paper presented to the Conference of the Islamic Financial Services II, Libya.

[6] Al-Taleb, Ghassan, (2013), The Governance in the Islamic banks from an Islamic perspective, The Al-gaed newspaper, Sunday, August 25.

[7] Bin Thabit, Adel and Abdi Naaima, (2010), The governance in the Islamic banks, Working paper submitted to the school day about: The Islamic Finance: Reality and challenges, Faculty of Economic Sciences Management Sciences, Amer Thlji University, Laghouat, Algeria.

[8] Farhan, Mohammed and Abdul Qader, Mohammed Amin, (2014), The governance in the Yemeni Islamic banks: An Applied Study, An Islamic Economic Studies, 20(2).

[9] Islamic Financial Services Board (IFSB), (2006), The guiding principles for controls institutions Management which are limited to provide the Islamic financial services, p. 6.

[10]Joudeh, Fikri Abdul Ghani, (2008), Extent of application of the corporate governance principles in the Palestinian banks, Economic Cooperation and Development (OECD) and the principles of the Basel Committee on Banking Supervision, Master Thesis (unpublished).

[11]Sahih Muslim, Book of Faith - Door of statement that the Prevention of Vice of the faith, and that the faith increasing and decreasing (1/69), edition of Mohamed Fouad Abdul Baqi.

[12] Sami, Magdy Mohammed, (2005), Role of the review committees in the corporate governance and its impact on the quality of the financial statements published in the Egyptian business environment, $5^{\text {th }}$ Conference of the corporate and its accounting, administrative, and economic dimensions, Alexandria University, Faculty of Commerce.

[13] Suleiman, Mohammed Mustafa, (2006), corporate governance and address the financial and administrative corruption, $1{ }^{\text {st }}$ Edition, The University Aldar, Egypt. 